鉄骨鉄筋コンクリート柱部材の復元力特性に関する研究

一単一 H 形鋼を内蔵した SRC 柱の骨格曲線の定式化一

\title{
HYSTERESIS CHARACTERISTIC OF STEEL REINFORCED CONCRETE BEAM-COLUMNS
}

Formulae on skeleton curves of SRC beam-columns encased $\mathrm{H}$-shaped steel

\author{
堺 純一*，松井千 秋**
}

Junichi SAKAI and Chiaki MATSUI

\begin{abstract}
Formulae of hysteresis characteristic of SRC columns encased simple $\mathrm{H}$ shapsed steel were proposed. Dimensions of encased steel, strength of materials, hoop ratio and axial load ratio were selected as analytical parameters and skeleton curves were calculated by the elastic-plastic analysis. Hysteresis curves was supposed to consist of the following four points; happening point of transverse tension crack, yield point, maximum strength point and the point under strength deterioration. Effect of the parameters on the strength and rotation angle of the four points was discussed and the regression curves were studied.
\end{abstract}

Keywords: loading test, elastic-plastic analysis, shear span ratio, axial load ratio, strength of materials, hoop ratio

載荷実験, 弾塑性解析, せん断スパン比, 軸力比, 材料強度, せん断補強筋比,

1. 序

各種建築構造物の構造設計は今後, 性能設計さらに限界状態設計へ と移行する状況にあり, 特に限界状態設計では, 使用限界状態および 終局限界状態, その他の限界状態を設定し, それぞれに対して設計を 行うことになるものと思われる. 外力が骨組に作用するときの, それ らの限界状態に対して, 耐力のみならず変形も考慮し, 部材, 水平抵 抗要素およびそれらを組み合わせた骨組の適切な復元力特性を考えて おく必要がある。

鉄骨鉄筋コンクリート(以下SRC)柱部材は鉄骨と鉄筋コンクリート とを合成した部材であるため,部材の弾塑性挙動に及ほす影響因子が 複雑であり，復元力特性に対して未だ明らかにされているとは言い難 い点がある.SRC部材の復元力特性の研究は立花, 土井等によってな されており,立花等は部材の載荷実験結果をもとに実験式を中心に曲 げ破壊先行型の柱部材の復元力特性を定量的に検討している゙.土井 は力学モデルを取り入れることにより復元力特性のモデル化を行い, 曲げ破壊およびせん断破壊に対する復元力特性の定式化を行っている 2).しかしながらこれらは作用軸力, 鋼材およびコンクリートの材料 強度およびせん断補強筋量の違いなどが復元力特性に及ぼす影響につ いては検討されていない.

本研究では, 曲げ破壊先行型のSRC部材を対象とし, 復元力特性が
骨格曲線と履歴ループで構成されるものと考え, その骨格曲線が 4 つ の特異点, すなわち曲げひび割れ発生点, 降伏点, 最大酎力発揮点, 最大耐力発揮後の耐力劣化域上の点, からなるものとした. 柱部材の 載荷実験抢上び弾塑性解析を行い，これら4つの特異点に及ほす，材 料強度, 内蔵鉄骨量, せん断補強筋量, 軸力比の影響を検討し, それ らをもとに骨格曲線を定式化した。

$\mathrm{SRC}$ 断面の内蔵鉄骨の形状は種類が多く, 単一 $\mathrm{H}$ 形鋼を用いたも の, 十字形さらにL字形に組んだ鋼材を内蔵させたものがあるが，そ れらの内蔵鉄骨の形状により柱の弾塑性挙動は大きく異なるものと考 えられる。本論文では SRC 柱で最も基本的なものである単一 $\mathrm{H}$ 形鋼 を強軸曲げに配したSRC断面を対象としており，その他の内蔵鉄骨に ついても今後検討を行う予定である.

\section{2. 実験計画}

\section{1 試験体および実験変数}

一定軸力と繰返し水平力を受けるSRC柱部材の弾塑性挙動を調べる ために，図1に示すような片持柱試験体を10体製作した。試験体断面

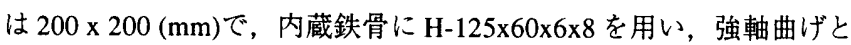
なるように配している.せん断補強筋は $4 \phi$ の鉄筋を用い, $4 \mathrm{~cm}$ 間隔で 配筋している（せん断補強筋比 $\mathrm{pw}=0.31 \%)$ 。ただし, 平行部の重ね部
本論文は文献4)－6)に加筆，修正を加之たものである。

* 九州大学大学院人間環境学研究科 助手. 工修

***州大学大学院人間環境学研究科 教授 ·工博
Research Assistant, Division of Architecture, Graduate School of HumanEnvironment Studies, Kyushu University, M. Eng.

Prof., Division of Architecture, Graduate School of Human-Environment Studies, Kyushu University, Dr. Eng. 
分を溶接することにより閉鎖型フープとした．

$\mathrm{SRC}$ 柱の弾塑性挙動に及ほすせん断スパン比と軸力比の影響を検討 するために, 実験変数としてこれらを選んだ (表1参照). せん断スパ ン比は2〜6までの 5 種類としており, 材長を変化させることにより 調整した. 軸力比nはSRC断面の圧縮耐力に対する作用軸力の比とし, $0.1 ， 0.3 ， 0.5$ とした（せん断スパン比 3 では軸力比が 0.4 の柱も加え た).これらの軸力は鉄骨鉄筋コンクリート構造計算規準 ${ }^{3}$ (以下 SRC 規準と略記）に規定された制限軸力の 0.28 倍，0.85倍，1.41倍である (軸力比 0.4 では 1.1 倍).

材料の機械的性質およびコンクリートの調合をそれぞれ表 2 と表 3 に示す、コンクリートのシリンダー強度を表 4 に示す。

\section{2 加力装置と測定方法}

加力装置は柱脚固定，柱頭ピン支持の境界条件となるようにした (図 2 参照). 載荷は500tonf万能試験機で柱頭に圧縮軸力を載荷し, 一 定に保持した状態で, 水平力を, $3 / 100 \mathrm{rad}$ までは5/1000 rad. を単位と し，それ以降は $1 / 100 \mathrm{rad}$ を単位として，各変位振幅で 2 回繰返す漸 増変位振幅で準静的に載荷した. 軸力は 500tonf 試験機の計測装置で, 水平力はオイルジャッキ先端に取り付けたロードセルで測定した.変 位は, 試験体の基礎梁から取り出したフレームに変位計を取り付け, 柱頭水平変位を測定した。

\section{3. 実験結果}

\section{1 崩壊性状}

各試験体とも部材奥が5/1000rad.までにコンクリートに曲げひび割 れが生じ, 1/100 rad. 前後からコンクリートの圧壊が生じ始めた。軸力 比が 0.1 の試験体は固定端からコンクリート断面せいcD離れた範囲内 でかぶりコンクリートの損傷が生じているが, 主筋の座屈は認められ なかった。軸力比が $0.3,0.4$ および 0.5 の試験体ではせん断スパン比 に関わらず固定端から $1.5 \cdot \mathrm{cD}$ の範囲内での破壊が著しい. 軸力比 0.3 の試験体では, 部材角が $2 / 100 \mathrm{rad}$. 前後でかぶりコンクリートが剥落 し，その後，主筋の座屈が目視により確認できた．軸力比が $0.4,0.5$ の試験体では部材角が 3/200〜 2/100rad. で損傷が激しい. 軸力比 0.1 以外の試験体では, 主筋の座屈発生後, 女ん断補強筋が隅角部で破断 し，抵抗力が急激に低下した. 図3に，コンクリートが剥離した後の， 目視により確認した主筋の座屈発生点をム印で示している。

\section{2 弾塑性挙動}

図 3 に水平力 $\mathrm{H}$ - 部材角 $\mathrm{R}$ 関係を示す. 図中, 実線および点線は塑 性崩壊機構直線であり, 固定端に塑性ヒンジが形成されるとして求め

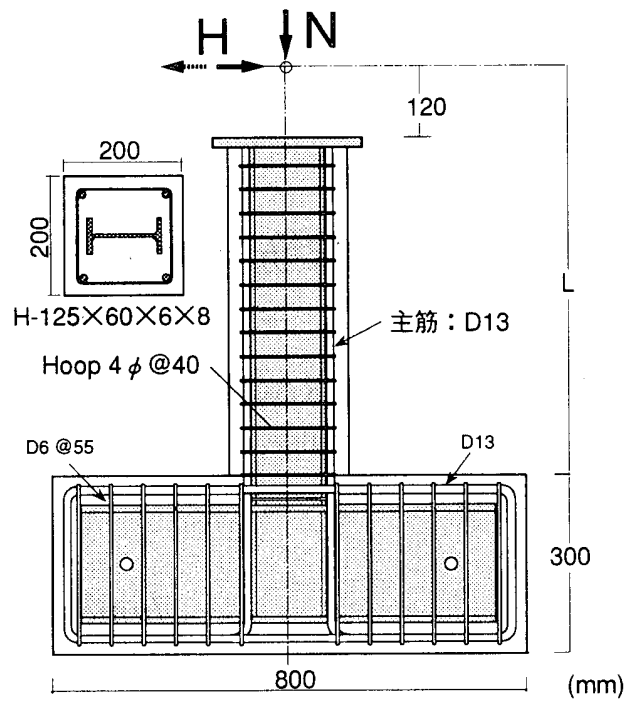

図 1 試験体

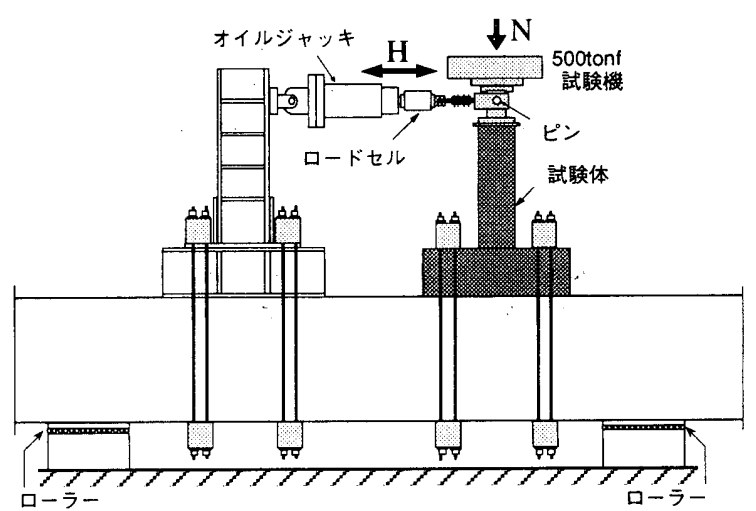

図 2 加力装置

ている．塑性ヒンジでの抵抗モーメントは実線が鋼材の降伏応力度

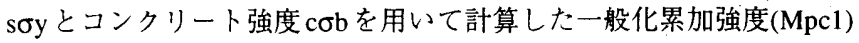
であり，点線は鋼材の降伏応力度とコンクリートの圧縮強度をSRC規 準に基づき低減したもので計算した累加強度 $(\mathrm{Mpc} 2)$ である. 全試験体 とも鋼材の降伏応力度とコンクリート強度を用いて計算した一般化累 加強度 Mpc1に達しており，精度よく実験耐力を評価している．柱の 最大曲け酎力はせん断スパン比および軸力の違いに拘わらず,かぶり コンクリート部分の圧壊で決まっている.履歴挙動は全ての試験体で 紡錘形の履歴性状を示しており, 軸力比が 0.1 の試験体は抵抗モーメ ントの低下は認められず部材角6/100rad.まで安定した挙動を示してい
表 1 実験条件

\begin{tabular}{c|c|c}
\hline 試験体名 & せん断スパン比 & 軸力比 \\
\hline H-23 & 2 & 0.3 \\
\hline H-31 & & 0.1 \\
H-33 & 3 & 0.3 \\
H-34 & & 0.4 \\
H-35 & & 0.5 \\
\hline H-43 & 4 & 0.3 \\
\hline H-51 & & 0.1 \\
H-53 & 5 & 0.3 \\
H-55 & & 0.5 \\
\hline H-63 & 6 & 0.3 \\
\hline
\end{tabular}

表 2 鎆材の機械的性質

\begin{tabular}{|c|c|c|c|c|c|c|}
\hline 鋼材の種類 & 規格 & $\begin{array}{c}\text { 降伏応力度 } \\
\sigma y(\mathrm{MPa}) \\
\end{array}$ & $\begin{array}{l}\text { 引張強度 } \\
\text { ou (MPa) }\end{array}$ & 降伏比 & 伸び & 備考 \\
\hline \multirow{2}{*}{$H-125 \times 60 \times 6 \times 8$} & \multirow{2}{*}{ SS400 } & 328 & 464 & 0.71 & $32.2 \%$ & フランジ \\
\hline & & 349 & 471 & 0.74 & $34.5 \%$ & ウエブ \\
\hline D13 & SD345 & 378 & 564 & 0.67 & $26.6 \%$ & 主筋 \\
\hline $4 \phi$ & SGD B & 378 & 478 & 0.79 & $22.0 \%$ & 帯筋 \\
\hline
\end{tabular}

表 3 コンクリートの調合

\begin{tabular}{c|c|c|c|c}
\hline コンクリート種類 & 設計強度 & スランプ & 水セメント比 & 細骨材比 \\
\hline 普通セメント & $26.5 \mathrm{MPa}$ & $18 \mathrm{~cm}$ & $49 \%$ & $44.1 \%$ \\
\hline \hline 亦 & セメント & 細骨材 & 粗骨材 & 混和剂 \\
\hline $190 \mathrm{~kg} / \mathrm{m}^{3}$ & $388 \mathrm{~kg} / \mathrm{m}^{3}$ & $724 \mathrm{~kg} / \mathrm{m}^{3}$ & $1,020 \mathrm{~kg} / \mathrm{m}^{3}$ & $0.97 \mathrm{~kg} / \mathrm{m}^{3}$ \\
\hline
\end{tabular}




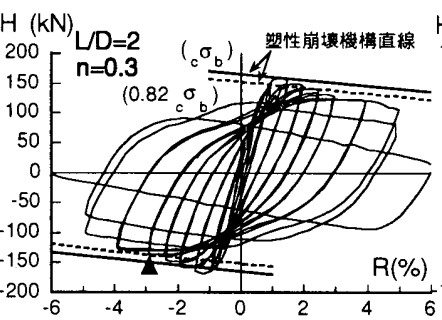

(a) $\mathrm{H} 23$

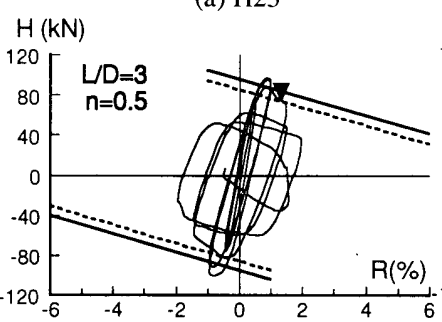

(e) $\mathrm{H} 35$

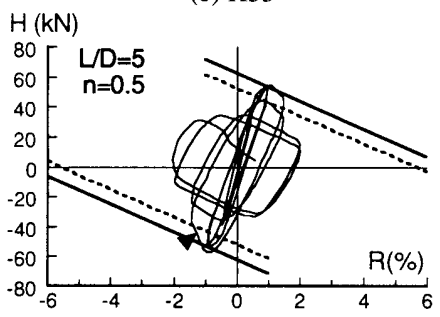

(i) $\mathrm{H} 55$

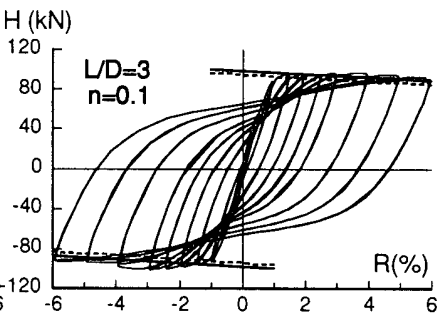

(b) $\mathrm{H} 31$

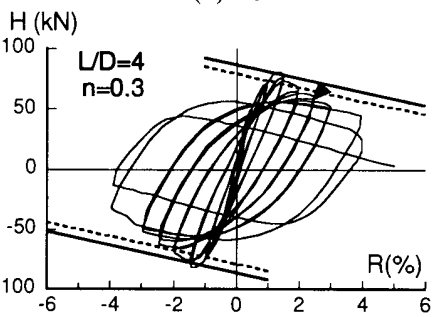

(f) $\mathrm{H} 43$

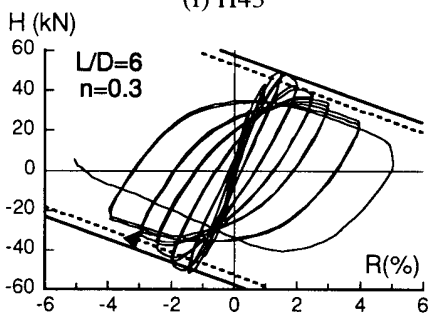

(j) $\mathrm{H} 63$

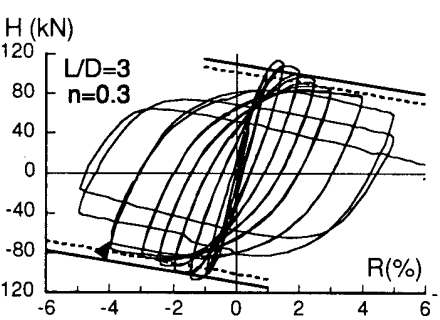

(c) $\mathrm{H} 33$

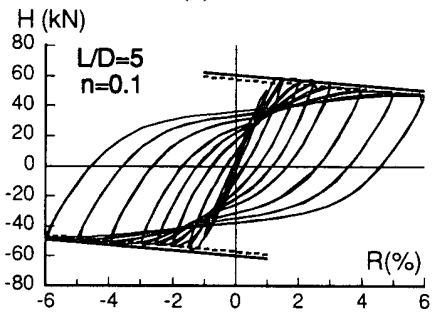

(g) $\mathrm{H} 51$

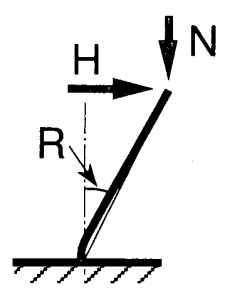

図 3 水平力 - 部材角関係

る. 軸力比が 0.3 以上の試験体は最大耐力発揮以降コンクリートの圧 壊および剥落により耐力が徐々に低下しており, 主筋の座屈発生後, 帯筋が破断したため耐力が急激に低下している.しかしながらこのよ うに卌力は低下しているものの，鉄筋コンクリート柱に見られる曲げ 降伏後のせん断破壊により軸力を保持できなくなる崩壊形とは異な り, 水平力が無くなる時点で実験を終了しているが，この時点まで軸 力を保持できている.

\section{4. 弾塑性解析}

\section{1 解析方法}

解析モデルを図4に示すように弾塑性ヒンジ部と剛体からなるモデ ルと考え, 柱部材の変形を弾塑性ヒンジ部に集中させ, その点での断 面のモーメント曲率関係を元に,力の釣り合いを満足させることによ り, 柱の挙動が説明できるものと考えた. 弾塑性ヒンジ部での断面の モーメント-曲率関係は平面保持の仮定のもとで断面区分法により求 めた、材料の応力 -ひずみ関係は図 5 に示すモデルを用いた．鋼材は 降伏後バウシンガー効果により軟化する現象を考慮している.コンク リートは包絡線に崎野・棌モデルを用い7, 繰返し則は渡辺らのモデ ルを用いた ${ }^{8)}$. さらに弾塑性ヒンジ部での曲率 $\phi$ と柱部材角 $\mathrm{R}$ の間に 次式が成り立つものと仮定した。

$$
R=\alpha \cdot L \cdot \phi
$$

\section{ここで, Lは固定端から柱頭までの片持柱の部材長さである.}

(1)式中, $\alpha$ の值を, 解析で得られた水平力 - 部材角関係の初期棡性 と実験結果のそれが等しくなるようにした。 $\alpha$ の值は軸力が無い片持 ち柱の曲げ変形の弾性理論解では $1 / 3$ となるが, 以下のことを考え, せ

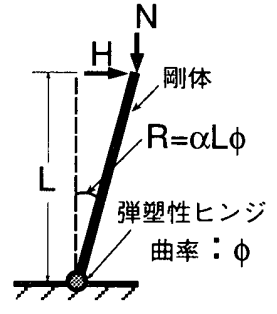

図 4 解析モデル (1)式が成り立つものと仮定した。

\section{2 解析結果}

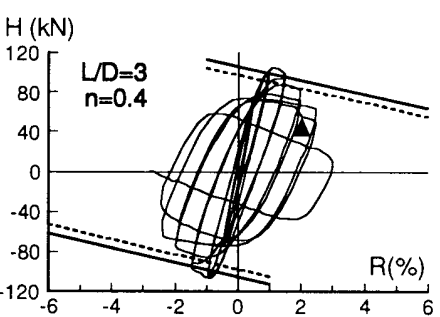

(d) $\mathrm{H} 34$

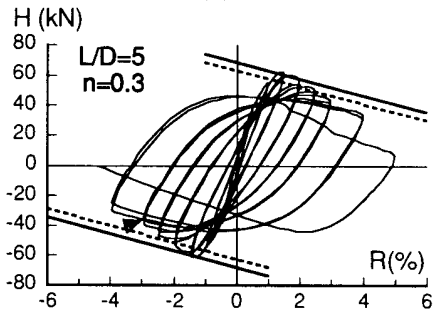

(h) H53

$\Delta, \boldsymbol{\nabla}$ : 主筋の座屈発生点を示す

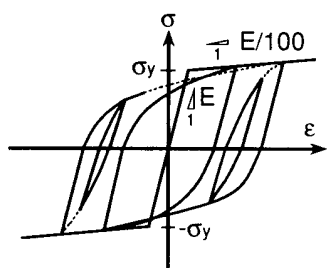

(a) 鉄骨および鉄筋

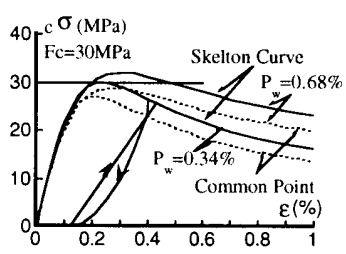

(b) コンクリート

図 5 材料の応力-歪関係

ん断変形および鉄骨,主筋の抜け出しによる付加変形を弾塑性ヒンジ部 の曲率の一部に含める形でこのような仮定を設けた. 鋼構造部材では座 屈等不安定現象が無ければ, 材端での抵抗力の上昇に伴い塑性域 ((1)式 の $\alpha$ と の積に対応する長さ) が材長方向に広がり(1)式の $\alpha$ の值は刻々 異なるが, コンクリート系の部材では最大耐力発揮後コンクリートの圧 壊により材端での抵抗力は減少し，それに伴い塑性域以外の部分は弾性 に留まるため, 塑性域は限定された区間となり, 柱部材角は材端での曲 率が支配的となる.柱の弾性変形および弾塑性変形に拘わらず,柱の部 材角は,材端での曲率が塑性域に対応する長さ内で一様に分布した状態 での変形で表されるものと考え,解析の簡便さと実験挙動との比較の妥 当性より, 弾性剛性を合わせることで, 弾性, 弾塑性の状態に拘わらず

図6に解析挙動と実験挙動の比較の例を示す. 初期剛性を合わせるこ とで, 主筋の座屈が生じる段階までの実験挙動を本解析により追跡でき ているものと考えられる、解析による最大水平耐力が実験耐力に比べ小 さく評価されているが,これは弾塑性解析では弾塑性ヒンジを柱脚固定 端にあるとしていること, 実験では危険断面が固定端よりも上に形成さ れ，スパンが短くなることにより，水平力 $\mathrm{Hで}$ 見たときの実験耐力が上 
表 4 実験結果

\begin{tabular}{|c|c|c|c|c|c|c|c|c|c|c|c|c|}
\hline \multirow{3}{*}{ 試験体 } & \multirow{3}{*}{$\begin{array}{c}c \sigma b \\
(\mathrm{MPa})\end{array}$} & \multirow{3}{*}{$\begin{array}{l}\text { 軸力 } \\
(\mathrm{kN})\end{array}$} & \multicolumn{4}{|c|}{ 実験 耐力 } & \multicolumn{2}{|c|}{ 計算耐力 } & \multirow{3}{*}{$\frac{\text { Mmax }}{\text { Mpc1 }}$} & \multirow{3}{*}{$\frac{M \max }{M p c 2}$} & \multirow{3}{*}{$\begin{array}{c}\mathrm{Lp} \\
(\mathrm{cm})\end{array}$} & \multirow{3}{*}{$\alpha$} \\
\hline & & & \multicolumn{2}{|c|}{$\mathrm{Hmax}(\mathrm{kN})$} & \multicolumn{2}{|c|}{$\operatorname{Mmax}(\mathrm{kN} \mathrm{m})$} & \multirow{2}{*}{$\begin{array}{c}\text { Mpcl } \\
(\mathrm{kN} \mathrm{m})\end{array}$} & \multirow{2}{*}{$\begin{array}{c}\mathrm{Mpc} 2 \\
(\mathrm{kN} \mathrm{m})\end{array}$} & & & & \\
\hline & & & 正側 & 負側 & 正側 & 負側 & & & & & & \\
\hline $\mathrm{H}-23$ & 27.5 & 533 & 160 & -169 & 67. & -70 & 66 & 61 & 1.04 & 1.13 & 30 & $0: 75$ \\
\hline $\mathrm{H}-31$ & 27.3 & 179 & 97 & -101 & 62 & -64 & 59 & 57 & 1.06 & 1.11 & 35 & 0.58 \\
\hline H-33 & 27.2 & 529 & 114 & -107 & 73 & -68 & 66 & 60 & 1.07 & 1.16 & 30 & 0.50 \\
\hline H-34 & 28.9 & 726 & 106 & -107 & 68 & -68 & 63 & 59 & 1.08 & 1.17 & 29 & 0.48 \\
\hline H-35 & 28.9 & 914 & 97 & -100 & 63 & -64 & 57 & 51 & 1.12 & 1.25 & 28 & 0.47 \\
\hline $\mathrm{H}-43$ & 30.5 & 567 & 81 & -82 & 71 & -72 & 69 & 63 & 1.04 & 1.13 & 32 & 0.40 \\
\hline H-51 & 28.2 & 180 & 59 & -55 & 62 & -59 & 60 & 57 & 1.01 & 1.06 & 40 & 0.40 \\
\hline H-53 & 29.7 & 558 & 63 & -61 & 71 & -69 & 68 & 63 & 1.03 & 1.12 & 35 & 0.35 \\
\hline H-55 & 29.7 & 930 & 55 & -57 & 65 & -66 & 62 & 52 & 1.05 & 1.25 & 33 & 0.33 \\
\hline H-63 & 30.5 & 567 & 50 & -51 & 69 & -71 & 69 & 63 & 1.02 & 1.11 & 35 & 0.29 \\
\hline
\end{tabular}

1） cob：コンクリートのシリンダー強度. 2) 実験耐力中, $\mathrm{Hmax}$ ：実験最大水平力, $M \max$ ：固定端における抵抗モーメントの最大

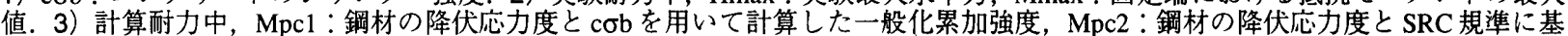
づきコンクリート強度を低隇して求めた一般化累加強度。4）Lp：(1)式中の曲率と部材角を関係づけるもので， $\alpha$ と材長 L との積。

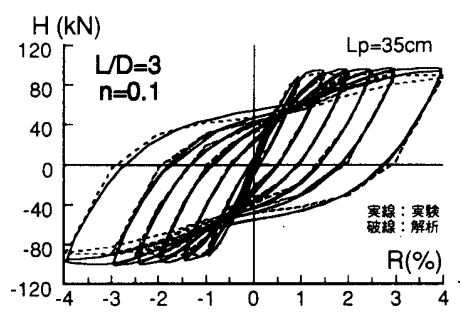

(a) $n=0.1$

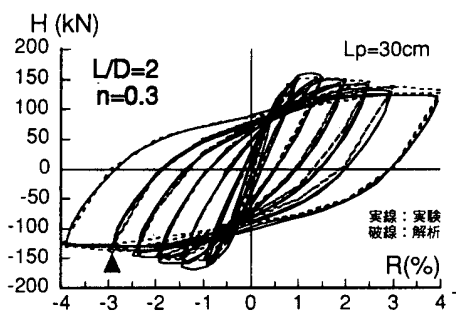

(e) $\mathrm{L} / \mathrm{D}=2$

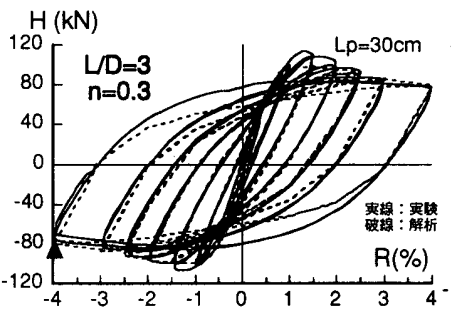

(b) $n=0.3$

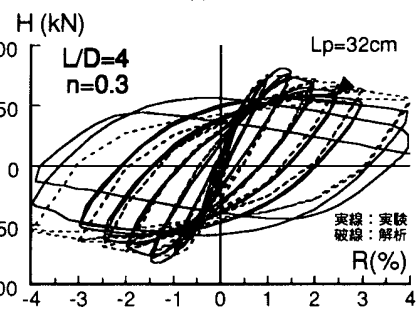

(f) $\mathrm{L} / \mathrm{D}=4$

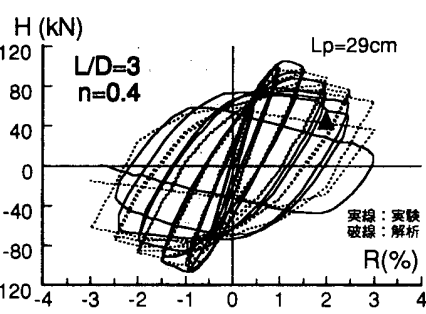

(c) $n=0.4$

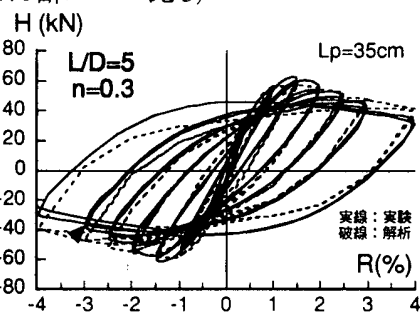

(g) $\mathrm{L} / \mathrm{D}=5$

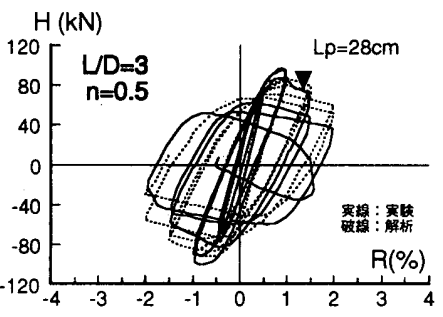

(d) $\mathrm{n}=0.5$

(ii) せん断スパン比の違い（軸力比 0.3）

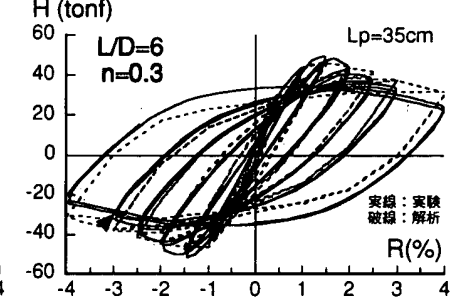

(h) $\mathrm{L} / \mathrm{D}=6$

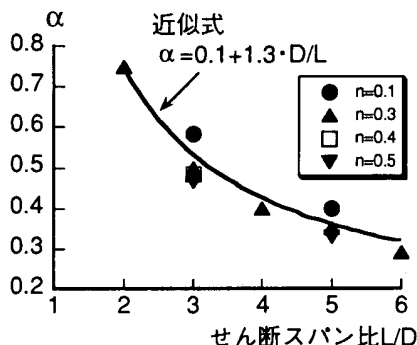

(a) 本実験結果

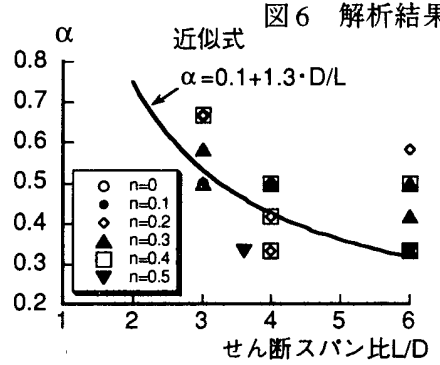

(b) 既往の SRC 柱の実験 $10 \sim 17$ )

図 7 曲率と部材角を関係づける $\alpha$

昇したためであると考えられる.なお, 本実験に用いたローラの静摩 擦係数は測定の結果 $0.1 \%$ 程度であり, 摩擦による実験耐力上昇はほ とんど無いものと考えられる.

図7(a)に上記の方法で算定した, 本実験の結果より得られた $\alpha$ の値 をプロットしている. 図中の曲線は本実験デー夕をもとにした回帰曲 線であり，下式が得られた。

$$
\alpha=0.1+1.3 \frac{c D}{L}
$$

ここで, $\mathrm{cD}$ は断面せいである

図7(b)にSRC柱の既往の実験に対する結果9)-16) と本近似式の比較を 示す. 本実験結果と同様であるが作用軸力の比が小さい場合近似曲線 は小さめの值を与えること, 軸力比が 0.3 程度以上となれば本評価式 は概ね妥当なものであると考えられる。

\section{5. 復元力特性の定式化}

\section{1 解析条件}

図8に示すSRC断面を対象とし，4章の解析モデルと解析手法を用 いて, 鉄骨寸法, 材料強度, 軸力比, せん断補強筋量を変化させ SRC 柱材の弾塑性解析を行った．解析变数を表 5 に示す. 復元力特性の骨 格曲線を曲げひび割れ点, 降伏点, 最大耐力発揮点, 最大耐力発揮後 の劣化域にある点,で構成されるものと考え（図9), 解析変数がこれ ら4つの特異点に及ほす影響を検討し，回帰的に骨格曲線の定式化を 行った。以降の各式にでてくる諸記号を以下にまとめて示す.

$$
d_{s}=\frac{{ }_{s} D}{{ }_{c} D}, n=\frac{N}{{ }_{s r c} N_{u}}, n^{\prime}=\frac{N}{{ }_{c} N_{u}}, f_{c}=\frac{{ }_{c} \sigma_{b}}{30 M P a}, f_{s}=\frac{{ }_{s} \sigma_{y}}{294 M P a}
$$

(3), (4), (5), (6),(7) 


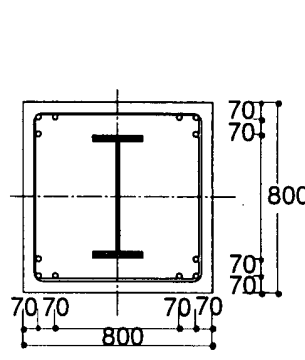

図 8 解析条件

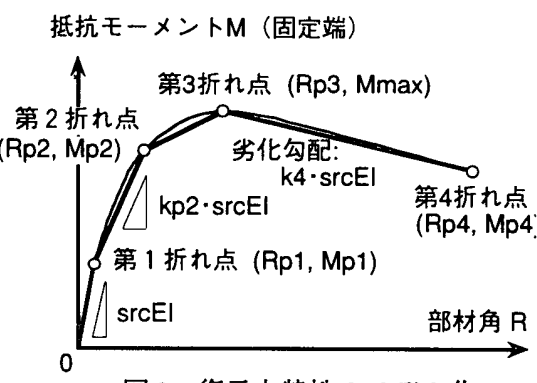

図 9 復元力特性のモデル化
ここで, $\mathrm{sD}, \mathrm{cD}$ は鉄骨およびコンクリート断面せい， Nは柱に作 用する軸力， ${ }_{\mathrm{Src}} \mathrm{N}_{\mathrm{u}, \mathrm{c}} \mathrm{N}_{\mathrm{u}}$ はそれぞれ $\mathrm{SRC}$ 断面およびコンクリート断面の 圧縮耐力, ${ }_{\mathrm{c}} \sigma_{\mathrm{b}},{ }_{\mathrm{s}} \sigma_{\mathrm{y}}$ はそれぞれコンクリートの圧縮強度, 内蔵鉄骨の降 伏強度,である。

\section{2 初期剛性}

断面のモーメント - 曲率関係（M- 関係）における初期剛性を（8） 式により求める.

$$
\begin{aligned}
& { }_{s r c} E I={ }_{s} E{ }_{s} I+{ }_{r} E \cdot{ }_{r} I+{ }_{c} E \cdot_{c} I \\
& { }_{c} E=21000 \cdot\left(\frac{\gamma}{23}\right)^{1.5} \cdot \sqrt{\frac{{ }_{c} \sigma_{b}}{20}} \quad(M P a)
\end{aligned}
$$

ここで, E:ヤング係数, I:断面二次モーメント, 添字のs,r,c:鉄骨, 鉄 筋，コンクリート， $\gamma$ コンクリート密度 $\left(\mathrm{kN} / \mathrm{m}^{3}\right)$ ，である。

\section{3 第 1 折れ点（曲げひび割れ発生点）}

第1折れ点をコンクリートの曲げひび割れ発生点とした.この点 は曲率の増大に伴い, 曲げ引張側コンクリートが引張歪となり M-ф関 係の㴊性が低下することに対応する点であり，(8)式で算定される初期 剛性を下回る点である. 図10に弾塑性解析を行った結果, 得られた曲 げひび割れ発生曲率 $\phi_{p 1}$ を示している。この曲率は軸力比およびコン クリート強度の違いによる影響を大きく受けるが, 他の因子の影響は 二者に比べ小さい. 回㷌分析の結果, 第 1 折れ点の曲率は (12) (15) 式で評価できる. 第1折れ点のモーメント $\mathrm{M}_{\mathrm{p} 1}$ および部材角 $\mathrm{R}_{\mathrm{p} 1}$ はそれ ぞれ（10)，(11）式で算定できる。 $\alpha$ (2) 式で得られる值である.

$$
\begin{aligned}
& M_{p 1}={ }_{s r c} E I \cdot \phi_{p 1} \\
& R_{p 1}=\alpha \cdot L \cdot \phi_{p 1} \\
& \phi_{p 1}=\frac{f_{11}+f_{12} \cdot n^{\prime}+f_{13} \cdot n^{\prime 2}}{{ }_{c} D} \cdot 10^{-3} \\
& f_{11}=-\left(4.9+3.9 \cdot f_{c}\right) / 100 \\
& f_{12}=1.65+2.1 \cdot f_{c} \\
& f_{13}=-\left(1.7+1.4 f_{c}\right)
\end{aligned}
$$

\begin{tabular}{|c|c|}
\hline $\begin{array}{l}\text { 1）内蔵鉄骨 } \\
\text { 寸法 }\end{array}$ & $\begin{array}{l}\text { 1) } \mathrm{H}-492 \times 198 \times 8 \times 12(1.3 \%), \\
\text { 3) } \mathrm{H}-518 \times 203 \times 13 \times 25(2.5 \%), 4) \mathrm{H}-524 \times 204 \times 14 \times 28(2.8 \%)\end{array}$ \\
\hline${ }_{s} \sigma_{y}$ & 1) 235, 2) 294,3$) 353 \quad(\mathrm{MPa})$ \\
\hline 3) ${ }_{c} \sigma_{b}$ & 1) 20, 2) 30,3$) 40$ \\
\hline 4）帯筋比pw & 1) $0.2 \%, 2) 0.4 \%, 3) 0.6 \%$ \\
\hline 5) 軸力比n & 0〜0.6まで0.1刻み $(n=N / s r c N u)$ \\
\hline 共通事項 & $\begin{array}{l}\text { コンクリート断面：800 x } 800 \text { mm } \\
\text { 主筋12-D25（SD345）、帯筋D13（SD345） }\end{array}$ \\
\hline
\end{tabular}

(12) 〜(15)式の評価式で得られる第1折れ点の曲率と弾塑性解析の 結果得られたものとの比較を図11に示す.コンクリート断面の圧縮耐 力に対する作用軸力の比 $\mathrm{n}^{\prime} か ゙ 0.6$ を越える範囲では本評価式は弾塑性 解析の曲率を大きく評価する傾向にあるが, n'が 0.6 以下では本評価 式は解析の結果を 90 1 110\%の範囲内で評価している(全データでの
表 5 解析変数

1)（）内は鉄骨比, 2) ${ }_{s} \sigma_{y}:$ 鉄骨降伏応力度, 3$)_{c} \sigma_{b}$ : コンクリート強度

評価式に対する解析值の比の平均值は0.96,変動係数は9.14\%である). 5.4 第2 折れ点（降伏点）

第2折れ点は柱部材の降伏点に対応する点であり, 引張り側フラン ジの降伏と圧縮側かぶりコンクリートの圧壊のどちらか早期に起こる 方で決まるものとし，(18-1）式に基づき算定する，図 12 に鉄骨の降 伏およびコンクリートの圧壊開始時曲率 $\phi_{2 \mathrm{~s}}, \phi_{2 \mathrm{c}}$ を示す. 回帰分析の 結果, それぞれの曲率は(19)および(20)式で評価できる. 図12よりSRC 断面の圧縮耐力に対する作用軸力の比 $\mathrm{n}$ が 0.3 を越える範囲では, こ の曲率は殆どコンクリートの圧壊で決まり, $\mathrm{n}$ が 0.1 以下では鉄骨フラ ンジの降伏で決まることがわかる. 第2折れ点の曲率に関する評価式 と弾塑性解析の結果の比較を図13に示す.本評価式は軸力比に拘わら ず弾塑性解析結果を 0.9 倍から 1.1 倍程度に評価している (平均値 1.01 , 変動係数 $2.83 \%$ ). ただし，コンクリートせいに対する鉄骨せいの比 dsが 0.6 より小さい場合, 内蔵鉄骨の降伏開始に伴うモーメント-曲 率関係の剛性の変化はあまり見られないことを考慮しこの場合の第 2 折れ点はコンクリートの圧壊で決まるものとする．

第 1 折れ点から第 2 折れ点までの剛性は初期剛性に対する剛比 $\mathrm{k}_{2}$ で 評価し，この值は第 2 折れ点の曲率によって異なり，第 2 折れ点がフ ランジの降伏で決まる場合（21）式で, コンクリートの圧壊で決まる 場合 $(22) \sim(25)$ 式で評価できる。

コンクリートの圧壊で決まる場合の $\mathrm{k}_{2 \mathrm{c} 3}$ については, 鉄骨せいのコ

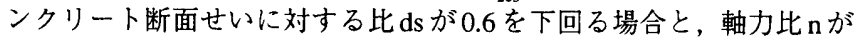
0.3を下回る場合は(25-1)式ではかなりの安全側の評価となるため,(252)〜(25-4)式で評価することにした.

この剛性の評価式と弾塑性解析の結果得られた剛性の比較を図14に 示す. 本評価式は弾塑性解析の結果を軸力比に拘わらず0.9 1.1 倍の 間で評価している(平均値 1.01, 変動保数 $3.36 \%$ ).

$$
\begin{aligned}
& M_{p 2}=M_{p 1}+k_{2} \cdot_{s r c} E I \cdot\left(\phi_{p 2}-\phi_{p 1}\right) \\
& R_{p 2}=\alpha \cdot L \cdot \phi_{p 2}
\end{aligned}
$$

(a) ds $\geqq 0.6$ の場合 : $\phi_{p 2}=\min \left(\phi_{2 s}, \phi_{2 c}\right)$

(b) ds $<0.6$ の場合 $\quad: \phi_{p 2}=\phi_{2 c}$

$$
\begin{aligned}
& \phi_{2 s}=\frac{2.9 f_{s}+\left(4.9+0.92 f_{s}\right) n}{{ }_{c} D} \cdot 10^{-3} \\
& \phi_{2 c}=\frac{\left(2.8+4.3 f_{c}-1.4 f_{c}{ }^{2}\right)-\left(2.1+5.6 f_{c}-2.0 f_{c}{ }^{2}\right) n}{{ }_{c} D} \cdot 10^{-3}
\end{aligned}
$$




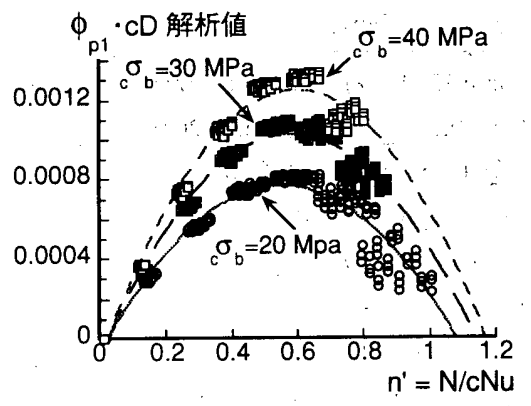

図 10 第 1 折れ点の曲率

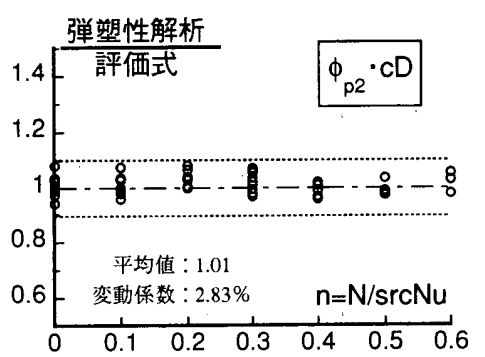

図 13 第 2 折れ点の曲率に関する 弾塑性解析と評価式の比較

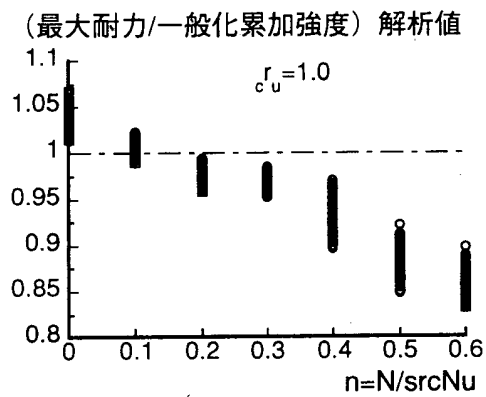

(a) $\mathrm{cru}=1.0$

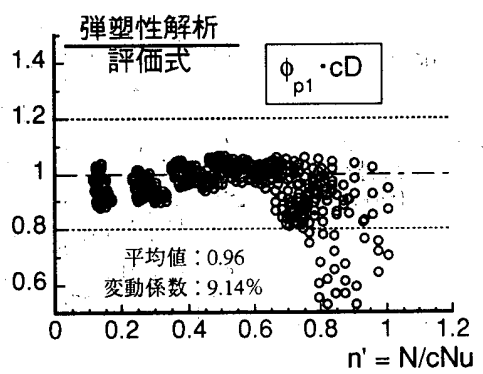

図 11 第 1 折れ点の曲率に関する 弾塑性解析と評価式の比較

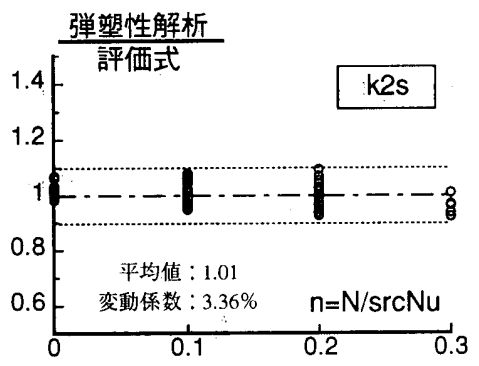

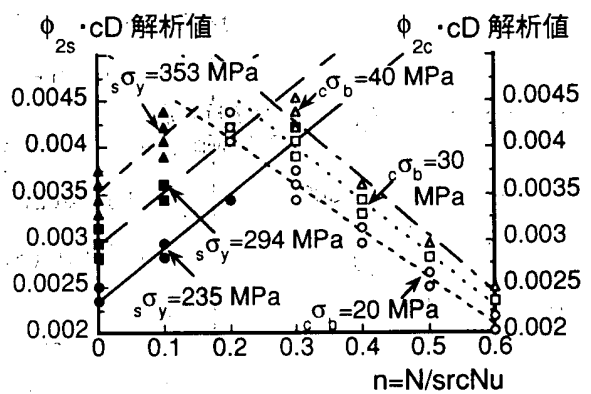

図 12 第 2 折れ点の曲率

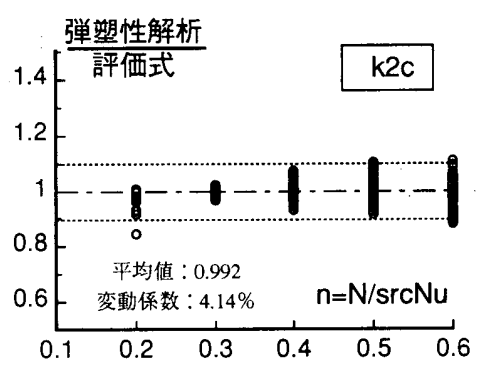

(a) 第 2 折れ点が鉄骨降伏で決まる場合 (b) 第2 折れ点がコンクリート圧壊で決まる場合 図 14 第 1 折れ点から第 2 折れ点間の剛性に関する弾塑性解析と評価式の比較

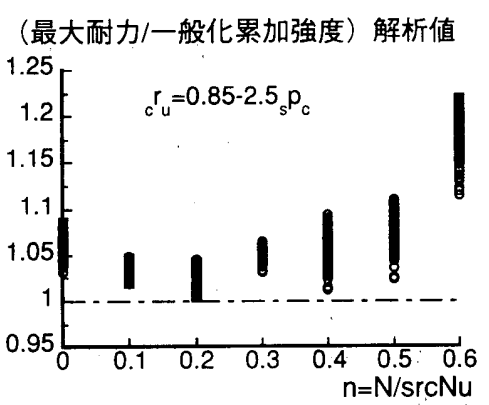

(b) $\mathrm{cru}=0.85-2.5 \mathrm{spc}$

図 15 最大耐力の一般化累加強度に対する割合

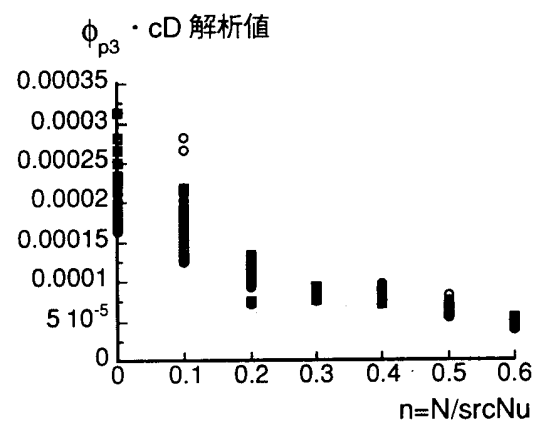

図 17 最大耐力発揮時曲率

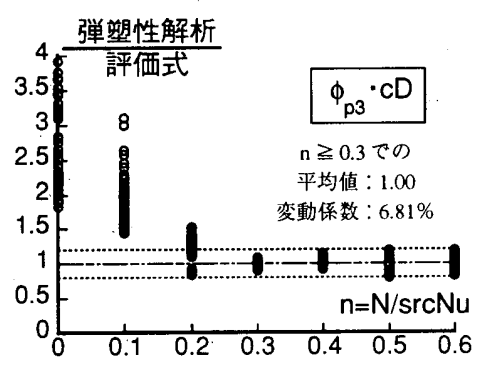

図 18 最大耐力発揮時曲率に関する 弾塑性解析と評価式の比較

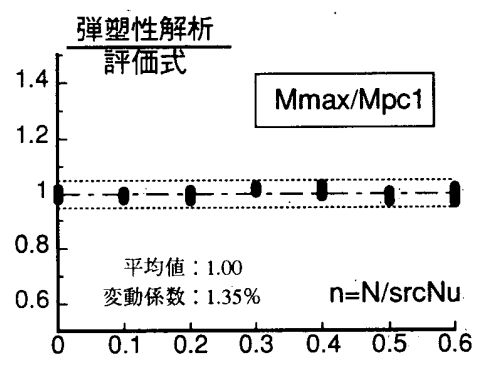

図 16 最大耐力 $/$ 一般化累加強度 $(\mathrm{cru}=1.0)$ に 関する弾塑性解析と評価式の比較

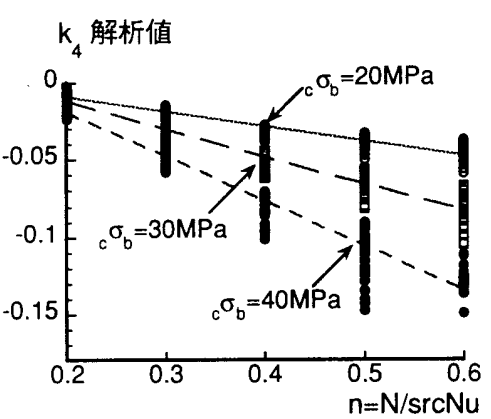

図 19 最大耐力発揮後の劣化勾配

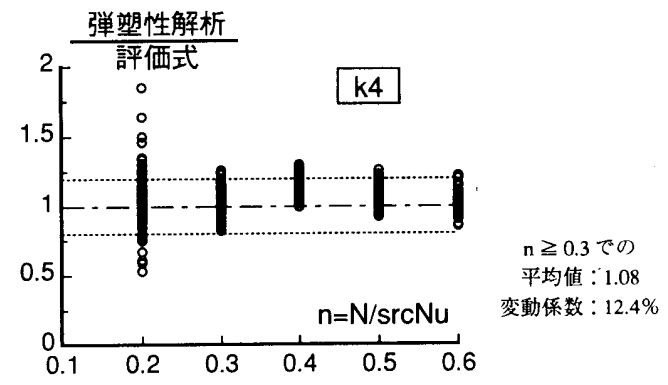

図 20 劣化勾配に関する弾塑性解析と評価式の比較 (i) 第 2 折れ点が鉄骨の降伏で決まる場合,

$$
k_{2}=k_{2 s}=\left(-1.05+2.3 d_{s}\right) \cdot\left(1.20-0.20 f_{s}\right) \cdot\left(1.2-0.24 f_{c}\right)
$$

(ii)第 2 折れ点がコンクリートの圧壊で決まる場合,

$$
\begin{aligned}
& k_{2}=k_{2 c}=k_{2 c 1} \cdot k_{2 c 2} \cdot k_{2 c 3} \\
& k_{2 c 1}=1.25\left(f_{s}-1\right) \cdot n-0.25\left(f_{s}-5\right) \\
& k_{2 c 2}=1.27-0.36 f_{c}+0.09 f_{c}^{2} .
\end{aligned}
$$

(a)n $\geqq 0.3$ かつ ds $\geqq 0.6$ の場合; 


$$
\begin{aligned}
k_{2 c 3}= & -22.8\left(d_{s}{ }^{2}-1.39 d_{s}+0.457\right) \\
& +104\left(d_{s}{ }^{2}-1.31 d_{s}+0.419\right) \cdot n \\
& -128\left(d_{s}{ }^{2}-1.27 d_{s}+0.39\right) \cdot n^{2}
\end{aligned}
$$

(b) $\mathrm{n} \geqq 0.3$ かつ ds $<0.6$ の場合,

$$
k_{2 c 3}=0.39-0.73 n+1.5 n^{2}
$$

(c) $\mathrm{n}<0.3$ かつ ds $\geqq 0.6$ の場合,

$$
k_{2 c 3}=-3.1 d_{s}^{2}+5.5 d_{s}-1.84
$$

(d)n<0.3 かつ ds<0.6の場合,

$$
k_{2 c 3}=0.34
$$

\section{5 第3 折れ点（最大耐力点）}

一般化累加強度, Mpc1（鋼材の降伏応力度及びコンクリート強度で 計算）および $\mathrm{Mpc} 2$ (鋼材の降伏応力度及びコンクリート強度を SRC 規準式 ${ }^{3)}$ に従い低減係数 ${ }_{\mathrm{c}} \mathrm{r}_{\mathrm{u}}$ を乗じた強度で計算）に対する最大抵抗 モーメントの上昇率をそれぞれ図 15 の(a)と(b)に示す，最大耐力を Mpc1で評価した場合, 軸力比の増大に伴い耐力比が小さくなり, $\mathrm{Mpc} 2$ で評価すると安全側の評価となる，最大抵抗モーメントを Mpc1 で評価した場合の耐力上昇率を（26）式で評価する，本評価式と弾塑 性解析で得られたものとの比較を図16に示す.軸力比に拘わらず本評 価式は解析結果を $0.95 \sim 1.05$ の範囲で評価している (平均值 1.00 , 変
動保数 $1.35 \%)$.

弾塑性解析の結果得られた最大耐力発揮時の曲率 $\phi_{\mathrm{p} 3}$ を図17に示す。 この曲率を（28）～(31)式で評価する. 図18に弾塑性解析の結果と本 評価式の結果の比較を示す. 本評価式は軸力比 $\mathrm{n}$ が 0.3 以上では解析 結果を $0.8 \sim 1.2$ の範囲で評価している（平均值 1.00 , 変動倸数 6.81 $\%$ ）。軸力比がそれ以下の範囲内では最大耐力発揮時の曲率が大きい が, その付近での耐力上昇率はわずかなものであるため,この曲率を 低めの評価となるようにした。

$$
\begin{aligned}
& \frac{M_{\max }}{M_{p c 1}}=\left(1.09-0.05 f_{s}\right)-0.32\left(1-0.25 p_{w}\right) n \\
& R_{p 3}=\alpha \cdot L \cdot \phi_{p 3}
\end{aligned}
$$

(a) $\mathrm{n} \geqq 0.3$ の場合 : $\phi_{p 3}=\frac{f_{31} \cdot f_{32}}{{ }_{c} D} \cdot 10^{-3}$

(b) $\mathrm{n}<0.3$ の場合 : $\phi_{p 3}=\frac{f_{33}}{{ }_{c} D} \cdot 10^{-3}$

$$
\begin{aligned}
f_{31}= & 7.2+3.0 p_{w}-2.4 p_{w}{ }^{2} \\
f_{32}= & \left(1.1+0.28 f_{s}\right) \cdot\left(0.34+1.3 f_{c}-0.61 f_{c}{ }^{2}\right) \\
& +\left(1.1+0.48 f_{s}\right) \cdot\left(0.19-2.2 f_{c}+1.1 f_{c}{ }^{2}\right) \cdot n
\end{aligned}
$$

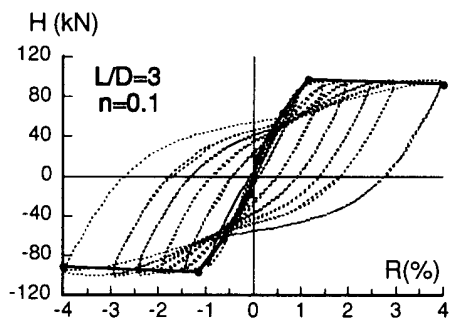

(a) $\mathrm{n}=0.1$

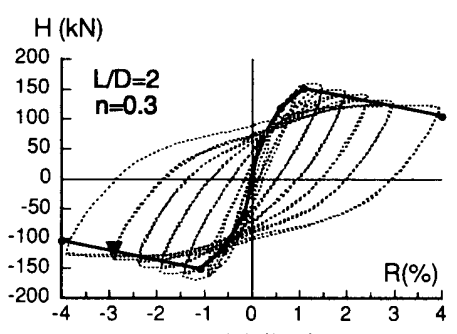

(e) $\mathrm{L} / \mathrm{D}=2$

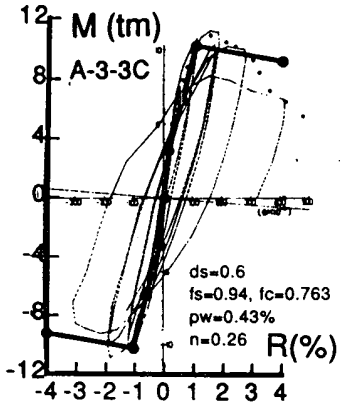

(i) 文献 16

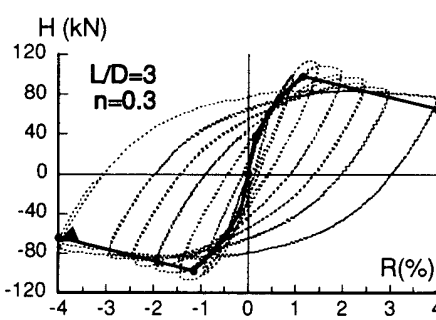

(b) $n=0.3$

(i) 軸力比の影

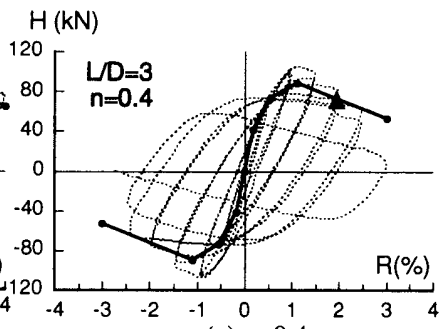

(c) $\mathrm{n}=0.4$

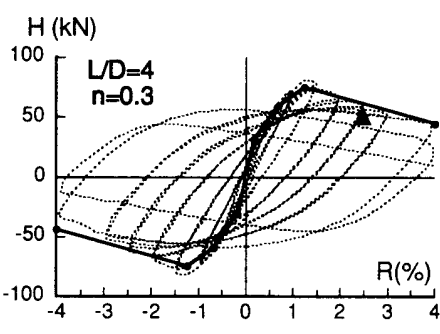

(f) $\mathrm{L} / \mathrm{D}=4$

(ii) せん断スパン比の影響

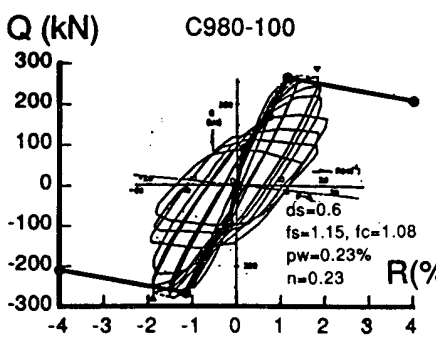

(j)文献 9

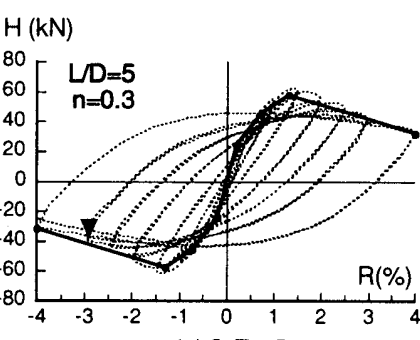

(g) $\mathrm{L} / \mathrm{D}=5$

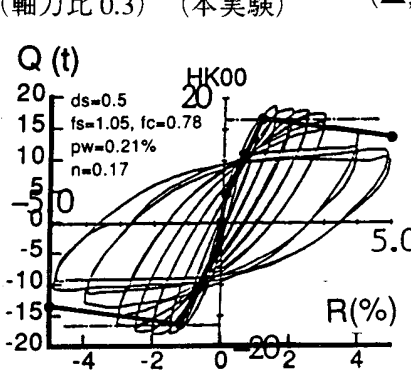

(k)文献 12

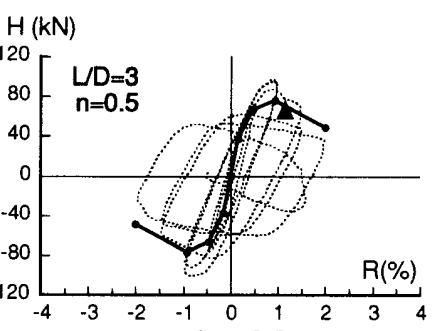

(d) $\mathrm{n}=0.5$

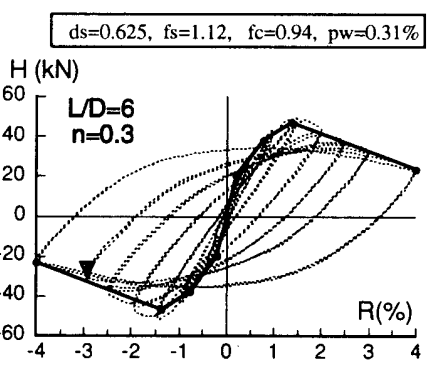

(h) $\mathrm{L} / \mathrm{D}=6$

$(\boldsymbol{\Delta}, \boldsymbol{\nabla}$ : 主筋の座屈発生点を示す.)

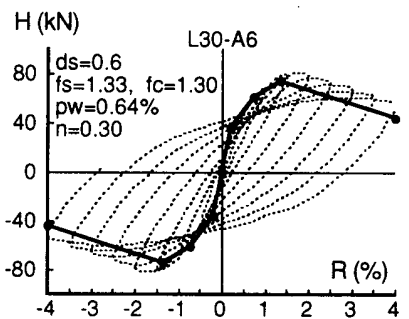

(l) 文献 17

(iii) 既往の実験挙動との比較

図 22 提案した復元力特性式と実験挙動の比較 


$$
\begin{aligned}
f_{33}= & -0.02(n-0.3) \\
& +\left(0.79+0.27 p_{w}-0.155 p_{w}{ }^{2}\right) \cdot\left(5.6+2.5 f_{s}\right)
\end{aligned}
$$

ここで, $\mathrm{p}_{\mathrm{w}}$ はせん断補強筋比(\%)である。

\section{6 最大耐力発揮後の劣化勾配}

最大耐力発揮以降の耐力低下率は初期剛性に対する剛比 4 によって 表すものとした. 最大耐力発揮後の劣化域では部材角 $\mathrm{R}_{\mathrm{p} 4}$ を設定しそ の部材角に対応する曲率 $\phi_{p 4}$ を(33)式より求め, その曲率に対するモ一 メント $\mathrm{M}_{\mathrm{p} 4}$ を(32)式および(34)〜(36)式で算定するものとした. 弾塑性 解析では, 安全㑡の評価となるように, この劣化勾配をコンクリート の強度低下を大きく取るために，部材角 $4 / 100 \mathrm{rad}$. の点と最大耐力点 から決まる勾配として求めた.弾塑性解析結果より得られた劣化勾配 係数 $\mathrm{k} 4$ を図 19 に示す. 回帰分析の結果 $\mathrm{k} 4$ は(34) 〜(36)式で評価でき る.解析では繰返し荷重による強度低下, 主筋の座屈等不安定現象を 考虑していないが, $2 / 100 \mathrm{rad}$. 程度の部材角ではそれらの影響は小さ いものと考え, 適用範囲としてはこの程度の変形までと考えている.

$$
\begin{aligned}
& M_{p 4}= M_{p 3}+k_{4} \cdot{ }_{s r c} E I \cdot\left(\phi_{p 4}-\phi_{p 3}\right) \\
& R_{p 4}= \alpha \cdot L \cdot \phi_{p 4} \\
& k_{4}= k_{41}-k_{42} \cdot n \\
& \mathrm{k}_{4}<0 \text { の場合 }: k_{4}=0 \\
& k_{41}=\left(1.0-1.4 d_{s}\right) \cdot\left(1.7 f_{c}-0.69\right) \\
& \cdot\left(0.31-0.29 p_{w}+0.27 p_{w}{ }^{2}\right) \\
& k_{42}=\left(5.2-6.6 d_{s}\right) \cdot\left(1.5 f_{c}-0.48\right) \cdot\left(0.22-0.092 p_{w}\right)
\end{aligned}
$$

本評価式と弾塑性解析の結果の比較を図 20 に示す，k4が正の值の 場合,(34-2)式に従い0としている. 軸力比が小さい場合は本評価式の ばらつきは大きいが, 軸力比 $0.3 \sim 0.6$ の範囲内では $0.8 \sim 1.2$ の範囲 内で評価している(平均値 1.08 , 変動係数 $12.4 \%$ ).

\section{7 提案式と実験結果との比較}

提案式を(37) 式に従い水平力と部材角に变換した結果と, 本実験 および既往の実験の挙動との比較の例を図 22(a)〜(1)に示す。

$$
H=M / L-N \cdot R
$$

最大耐力は実験結果を安全側に評価しているが,最大耐力以降の劣 化勾配を含め，本解析結果は概ね実験挙動を予測できている.

\section{6 まとめ}

単一H形鋼を内蔵した SRC 柱部材の載荷実験および柱の弾塑性解 析を行い, 鋼材寸法, 鋼材とコンクリートの材料強度, せん断補強筋 量および軸力比，がSRC柱の復元力特性に及はす影響を検討した。 そ の結果を元に, 鉄骨の降伏強度 $235 \sim 353 \mathrm{MPa}$, コンクリート压縮強度 $20 \sim 40 \mathrm{MPa}$, せん断補強筋比 $0.2 \% \sim 0.6 \%$, 軸力比 $0 \sim 0.6$ の範囲内 で, 曲げ破壊先行型のSRC柱の復元力特性の骨格曲線の定式化を行っ た、本実験および既往の実験の弾塑性挙動と本提案式を比較した結 果，本提案式は実験挙動を概ねよく評価していることを示した。
謝辞

試験体の製作に際し，津賀山健次技官，松岡直人技官，九州大学大 学院生, 李涛, 児玉憲助, 山崎和広諸氏の協力を得た. 実験に際し, 川口晃技官, 九州大学院生, 李麗氏の協力を得た。研究討議および資 料整理に際し，笠義秀氏 (竹中工務店), 池田俊也氏（現大林組）の 協力を得た。ここに深甚なる謝意を表します。

\section{参考文献}

1）立花正彦, 森田耕次, 中野清司：曲げ破壊型鉄骨鉄筋コンクリー 卜部材の復元力特性に関する実験的研究, コンクリート工学年次 論文報告集 9-2，pp.513-518，1987。

2）土井希祐：鉄骨鉄筋コンクリート部材の荷重 - 変位履歴特性モデ ルに関する研究，コンクリート工学年次論文報告集 Vol.17, No.2, pp. 1143-1148, 1995.

3）日本建築学会：鉄骨鉄筋コンクリート構造計算規準・同解説, 1987.6.

4）池田俊也，堺純一，松井千秋：鉄骨鉄筋コンクリート部材の復元 力特性に関する研究, 日本建築学会学術講演梗概集, pp.1043$1044,1998.9$

5）池田俊也, 堺純一, 松井千秋, 李麗: 鉄骨鉄筋コンクリート部材 の復元力特性に関する研究 その 2 部材の載荷実験および弾塑 性解析, 日本建築学会学術講演梗概集, pp.1107-1108, 1999.9.

6）堺 純一, 松井千秋, 池田俊也 : 鉄骨鉄筋コンクリート部材の復元 力特性に関する研究 その 3 復元力特性の定式化, 日本建築学 会学術講演梗概集, pp.1109-1110, 1999.9.

7）崎野健治, 孫玉平: 直線型横補強材により拘束されたコンクリー 卜の応力-歪み関係, 日本建築学会構造系論文集, 第461号, pp.95104, 1994.7

8）鎌田圭次郎，大住和正，渡辺史夫，六車 熙：各種強度の鉄筋混 使用による RC 断面曲げ性能の制御」, 日本建築学会大会学術講演 梗概集（東北）構造 II,B；,pp.505-506, 1991. 9.

9）仲威雄, 森田耕次, 立花正彦 : 鉄骨鉄筋コンクリート柱の耐力と 履歴特性に関する実験的研究 (その2), 日本建築学会論文報告集 第 260 号, pp. 47-58, 1977.10

10）若林實, 南宏一, 中村武：繰返しせん断力を受ける鉄骨鉄筋コン クリート柱の履歴特性に関する実験的研究, 京大防災研究所年報 第 15 号 B, pp. 69-97，1972.4

11）社団法人鋼材俱楽部·SRC 造への高張力鋼適用に関する調查研究 会: 高張力鎆を用いたSRC構造の開発研究, 圧縮力と綝返し曲げ を受ける柱の実験, pp.151-191. 1989.

12）西村繁, 斉藤文孝, 上原広, 西村泰志, 南宏一：偏心した鉄骨を 有する鉄骨鉄筋コンクリート柱の曲げ破壊性状に関する実験的研 究 (その 1 〜の 2 ), 日本建築学会学術講演梗概集, pp. 1697-1700, 1991.9

13）日笠英之, 宮内靖昌, 藤田幸二, 西村泰志, 南宏一: 高強度のコ ンクリートと鉄骨を用いたSRC柱の曲げ破壊性状 (その2), 日本 建築学会学術講演梗概集, pp. 1745-1746, 1994.9

14）松井千秋, 津田恵吾, 江冠華：高張力鋼を用いた H 形鋼を内蔵し たSRC柱材の耐力と挙動について（その1), 日本建築学会学術講 演梗概集, pp. 1431-1434, 1988. 10.

15）江冠華：鉄骨鉄筋コンクリート構造柱部材の安定限界軸力に関す る研究, 九州大学学位論文, 1991.11

16）加藤勉, 秋山宏, 称原良一：鉄骨鉄筋コンクリート柱の曲げせん 断破壊に関する研究 2, 日本建築学会学術講演梗概集, pp. 12091210, 1975.10 .

17）堺純一, 松井千秋, 南 宏一, 平川葉子：芯鉄骨合成柱の耐震 性能に関する実験的研究, 日本建築学会構造系論文集, pp.201208, 1999.12 . 